\author{
Holger Rajavee
}

\title{
ON TÕNIS TATAR'S PHD THESIS THE THIRD WAY IN SOVIET ESTONIAN ART: BETWEEN THE AVANT-GARDE AND THE POWER-MINDED
}

On 18 June 2015, Tõnis Tatar successfully defended his thesis The Third Way in Soviet Estonian Art: Between the Avant-garde and the Power-minded". Based on three significant authors in Estonian art history - Jüri Arrak, Olev Maran and Kaljo Põllu - Tatar proposes a new interpretation for a period in our art history that was filled with abundant changes but was also complicated and contradictory. The author's proposition starts in the second half of the 1960s and ends with 1987. The given period has been a focus of attention for our art historians and theoreticians since the last decades of the past century and it seems that the issues related thereto, which cause passionate disputes and often contrary interpretations, have not lost their topicality today. The purpose of this article is to highlight some significant aspects based on which - to use Sirje Helme's words - Tõnis Tatar's research paper is a work that cannot be ignored by any other forthcoming treatments related to the art history and theory of Estonian art.

The entire voluminous work proceeds from the author's deep conviction that art as such is a self-fulfilling phenomenon, the purpose of which

DOI: http://dx.doi.org/10.12697/BJAH.2015.9.10

Translation by Juta Ristsoo.

1 Supervisors: Prof. emer. J. Kangilaski, Prof. J. Maiste; opponents: prof. dr. J. Hackmann (University of Szczecin), Sirje Helme, PhD (Art Museum of Estonia). 


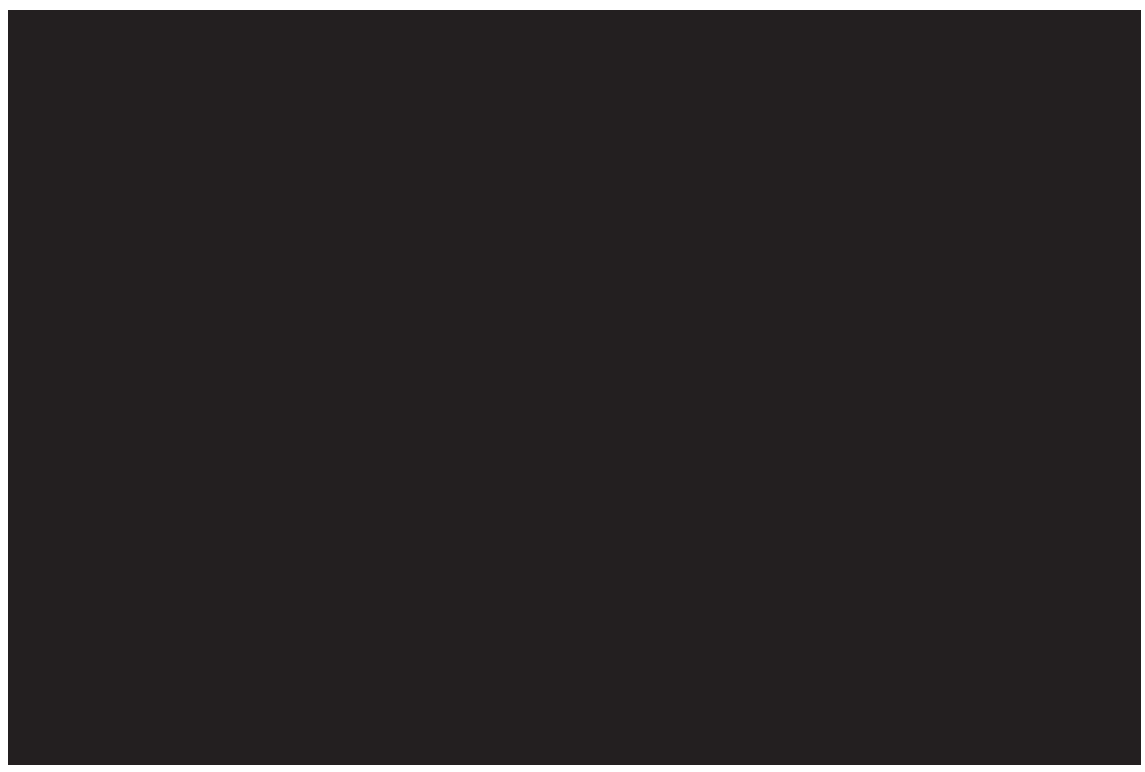

Fig. 1. Tõnis Tatar. Photo: Kristel Külljastinen.

is to provide the public with aesthetic experiences, to quote the author: "... generally we could define the "normal" function of art as providing the viewer aesthetic experiences and thereby the opportunity to give meaning to life through them ...". Tatar places the greatest importance on subjective artistic ambitions, the individual artist's purely personal world of thoughts and feelings, as the main source of creative impulses along with their temporal transformations and changes in direction. Considering the fact that during the last decades the predominant reception in our art history writing has been based on socio-political factors and treated the authors as "small cogs" subordinated to the rules of a system based on trends, Tatar's work seems very innovative and fresh, not to say "decadent" in the best meaning of the word.

The "third way" in Soviet Estonian art, a concept, which in its narrowest meaning was first launched by Jaak Kangilaski, has been logically expanded in this work. I dare to state that Tatar's "third way" is a significantly broader phenomenon than just an art trend, which can be positioned between the official ideological art and the art with avant-garde traits that was borne by a counter-culture spirit. This is the (re-) creation of a new paradigm-related niche, where the artist with his sin- 
gularity and artistic truth prevail as the final criteria of a work of art. Approached in this way, the "third way" can be applied to any art regardless of its traits.

In the case of the monographic approach to the three aforementioned artists, which comprise the core of the thesis, it is gratifying to see how the author is able to critically preserve the proper relationship between the emotional and analytical material, keeping both elegantly in balance. It is remarkable that Tatar uses the works of art as the most important primary sources for his research, which eloquently supports the main orientation of the thesis, i.e. that art is by nature independent and self-fulfilling. This approach could undoubtedly set an example for future authors of monographic approaches.

The author is not afraid to be provocative, considering the mainstream of our art writing - the preference of traditionalism over modernism is one of the work's recurrent themes. All three artists chosen by the author, having gone through the avant-garde experiment, gradually rejecting their earlier beliefs and moving forward (or backward?) toward art's traditional values. If a detached unconditional beauty that reaches the chosen one through light is the traditional basis for the evaluation of art, then one can figuratively speak of an emotion-filled striving from the darkness to the light. The beautiful imagery used in the author's paper, which is itself somewhat unexpected in a research paper, but also pleasantly refreshing, supports the aforementioned metaphor in every way. With the emphatic subjectivity of the presented opinions, in which total aesthetics is positioned on the main axis, is more reminiscent of a $19^{\text {th }}$-century text borne by romanticism and therefore contrasts even more with the means of expression inherent to the present day, which favours fuzzy ambivalence and reserved interpretations. I really hope that this path based on the aesthetics of pure beauty proposed in Tatar's analysis will not be the last and that others of the same mind will be found. The issue is not just the return to traditionalism but the fact that the given means of interpretation should also enable the examination and reassessment of art based on the paradigm of modernism. I am thoroughly convinced that the author (either academic or avant-gardist) is not "dead" in the least but has been left to wander too long in the labyrinth of the socio-ideological mainstream that has predominated.

In summary, it can be said that Tatar, by representing the younger generation of art historians, has accepted a sufficiently complicated 
assignment - to propose his own interpretation of a time period, the nature of which is complicated and overflowing with established myths. It is easy to fail if you do not possess the proper dose of critical mindedness. In addition, many of the "main characters" of the period under examination are still active in our art scene today. In this regard, I mean artists as well as art historians, and critics, who are producing their own "narratives" in which their own myths undoubtedly play an important role and the "third way" either directly or indirectly counters some of them. The undersigned must also admit that although he also wishes to dispute several parts of Tõnis Tatar's thesis, he must admit that the author has accomplished his task superlatively.

Holger Rajavee: On Tõnis Tatar's PhD thesis The Third Way in Soviet Estonian Art: Between the Avant-garde and the Power-minded

Keywords: Aesthetic Experience; Modernism vs Traditionalism; Beauty; “Third Way" in Art

CV:

Holger Rajavee is an external $\mathrm{PhD}$ candidate in University of Tartu's Department of Art History. He graduated from the University of Tartu in 1996 in art history, as has worked from 1996 to 2005 as a research fellow at the Tartu Art Museum. He is currently working at the University of Tartu's Viljandi Culture Academy and the Estonian Academy of Music and Theatre as a lecturer on art and cultural history. He has published articles on art criticism and theory, and curated numerous exhibitions. In his $\mathrm{PhD}$ thesis, he deals with philosophical and theoretical problems related to art that are associated primarily with aesthetics and the development of the artist persona more generally. 

